\title{
Development of Sequencing Batch Reactor Performance For Nitrogen Wastewater Treatment
}

\author{
Le $\mathrm{HT}^{1,2}$, Jantarat $\mathbf{N}^{1,2}$, Khanitchaidecha $\mathbf{W}^{1,2 *}$, Ratananikom $\mathrm{K}^{3 *}$ and Nakaruk $\mathrm{A}^{4}$ \\ ${ }^{1}$ Department of Civil Engineering, Faculty of Engineering, Naresuan University, Phitsanulok, Thailand \\ ${ }^{2}$ Centre of Excellence for Innovation and Technology for Water Treatment, Naresuan University, Phitsanulok, Thailand \\ ${ }^{3}$ Department of Science and Mathematics, Faculty of Agro-Industrial Technology, Rajamangala University of Technology Isan, Kalasin Campus, Kalasin, Thailand \\ ${ }^{4}$ Department of Industrial Engineering, Faculty of Engineering, Naresuan University, Phitsanulok, Thailand
}

\begin{abstract}
The performance of a typical sequencing batch reactor (SBR) for removing various nitrogen loadings was investigated in this study. The typical cycle of SBR consisted of filling of $5 \mathrm{~min}$, aerating of $3 \mathrm{~h}$, non-aerating of $4 \mathrm{~h}$, settling of $1 \mathrm{~h}$ and decanting of $5 \mathrm{~min}$ (HRT was approximately $24 \mathrm{~h}$ ). The results showed that the nitrogen removal efficiency was gradually increasing from $\sim 36 \%$ at the low $\mathrm{NH}_{4}-\mathrm{N}$ of $10 \mathrm{mg} / \mathrm{L}$ to $\sim 50 \%$ at the higher $\mathrm{NH}_{4}-\mathrm{N}$ of $20 \mathrm{mg} / \mathrm{L}$ and reached to the maximal efficiency of $82 \%$ at the highest concentration of $40 \mathrm{mg} / \mathrm{L}$. This is due to the increasing $\mathrm{NH}_{4}-\mathrm{N}$ and nitrogen removal rates which were 6.0 and $5.5 \mathrm{mg} / \mathrm{L} \cdot \mathrm{h}$ at the best reactor performance. Moreover, the high specific nitrogen removal rate of $20.5 \mathrm{mg} \mathrm{N} / \mathrm{g} \mathrm{MLVSS}$.h was found and the most effective carbon consumption of $2.4 \mathrm{mg} \mathrm{C} / \mathrm{mg} \mathrm{N}$ was obtained during the experiment.
\end{abstract}

Keywords: Ammonium concentration; Nitrogen wastewater; SBR cycle; Simultaneous nitrification and denitrification

\section{Introduction}

Since nitrogen has become a key factor for water pollution from eutrophication and oxygen depletion, the stringent environmental regulations are carried out to decrease the nitrogen discharge. For example, the effluent nitrogen standards of $35 \mathrm{mg} / \mathrm{L}$ for household wastewater and that of $100 \mathrm{mg} / \mathrm{L}$ for industrial wastewater were reported in Thailand [1]. In general, the high nitrogen of $40-70 \mathrm{mg} / \mathrm{L}$ was found in the household and sewage wastewater, which mainly contain ammonium-nitrogen $\left(\mathrm{NH}_{4}-\mathrm{N}\right)$ [2,3]. Some industries such as dairy and tannery also generate the high nitrogen wastewater in the range of $50-500 \mathrm{mg} \mathrm{NH}-\mathrm{N} / \mathrm{L}$ [4,5]. Moreover, the effluent from treatment system is one of significant sources for nitrogen wastewater discharge; the landfill leachate contained 250-600 $\mathrm{mg} \mathrm{NH}_{4}-\mathrm{N} / \mathrm{L}$ [6] and the anaerobic digestion effluent contained $710 \mathrm{mg} \mathrm{NH}_{4}-\mathrm{N} / \mathrm{L}$ [7]. According to the World Health Organization (2004), the consumption of high nitrate-nitrogen $\left(\mathrm{NO}_{3}-\mathrm{N}\right)$, the oxidized form of nitrogen, causes for blue baby syndrome in infants, and the $\mathrm{NH}_{4}-\mathrm{N}$ contamination leads to unpleasant taste and smell of water. To maintain the good quality of water resource, the treatment technology is required to reduce the nitrogen contamination to be the acceptable level.

The common technology for nitrogen removal is biological nitrification and denitrification. The contaminated $\mathrm{NH}_{4}-\mathrm{N}$ is oxidized to $\mathrm{NO}_{2}-\mathrm{N}$ and continued to $\mathrm{NO}_{3}-\mathrm{N}$ under high oxygen condition (named nitrification process), then the $\mathrm{NO}_{3}-\mathrm{N}$ is reduced to $\mathrm{N}_{2}$ releasing to the atmosphere under no oxygen condition (named denitrification process). The microorganisms involved in nitrification process have been reported; Nitrosomonas $s p$. and Nitrosococcus $s p$. for converting $\mathrm{NH}_{4}-\mathrm{N}$ to $\mathrm{NO}_{2}-\mathrm{N}[8,9]$, and Nitrobacter sp. and Nitrospira $s p$. for converting $\mathrm{NO}_{2}-\mathrm{N}$ to $\mathrm{NO}_{3}-\mathrm{N}[10,11]$. In the meanwhile, several microorganisms were suggested to involve in denitrification process including Ochrobactrum anthropi, Pseudonomas stutzeri, Alcaligenes faecalis, and Pseudomonas stutzer [12-14]. Recently, various wastewater treatment systems including sequencing batch reactor (SBR), movingbed biofilm reactor and intermittently aerated membrane bioreactor [15-17] were proposed for achieving simultaneous nitrification and denitrification. Among of the above mentions, the SBR is a widely used system in plants, due to its cost-effectiveness and ease operation. The conceptual of SBR operation includes four steps of filling, reacting, settling, decanting and idling. However, the periods of each step and its condition (i.e., $\mathrm{DO}$ and $\mathrm{pH}$ ) were various in previous studies. For example, Guo et al. operated the SBR containing a cycle of filling (instantaneous), reacting of $7.5 \mathrm{~h}$, settling of $0.5 \mathrm{~h}$, decanting (instantaneous) and idling of $4 \mathrm{~h}$ [18]. The hydraulic retention time (HRT) and DO value were $10 \mathrm{~h}$ and $0.5-1.0 \mathrm{mg} / \mathrm{L}$ respectively. The operating cycle was modified to enhance the nitrification and denitrification processes by including aerobic and anaerobic in the reacting period [19]. During the reacting period, there was air supply for $8 \mathrm{~min}$ and no air supply for $15 \mathrm{~min}$, and so on, until completing the $6 \mathrm{~h}$. The aim of this study was to evaluate the performance of SBR under a typical cycle for nitrogen wastewater treatment, and clarify the nitrogen removal mechanisms.

\section{Materials and Methods}

\section{Wastewater preparation}

The synthetic wastewater was used for evaluating the SBR performance. The composition was following (per liter); $\mathrm{NH}_{4} \mathrm{Cl} 0.04$ $0.15 \mathrm{~g}, \mathrm{KH}_{2} \mathrm{PO}_{3} 0.02 \mathrm{~g}, \mathrm{MgSO}_{4} 0.03 \mathrm{~g}, \mathrm{CaCl}_{2} 0.36 \mathrm{~g}, \mathrm{FeSO}_{4} 0.003 \mathrm{~g}$ and trace element $0.5 \mathrm{~mL}$ [20]. The $\mathrm{NH}_{4}-\mathrm{N}$ was step-wise increased from 10

*Corresponding authors: Khanitchaidecha W, Centre of Excellence for Innovation and Technology for Water Treatment, Naresuan University, Phitsanulok, Thailand, Tel: 6655964 224; E-mail: wilawank1@gmail.com

Ratananikom K, Department of Science and Mathematics, Faculty of Agro-Industria Technology, Rajamangala University of Technology Isan, Kalasin Campus, Kalasin, Thailand, Tel: 6681636 6649; E-mail: khakhanang_r@yahoo.com

Received September 30, 2015; Accepted October 12, 2015; Published October 19,2015

Citation: Le HT, Jantarat N, Khanitchaidecha W, Ratananikom K, Nakaruk A (2015) Development of Sequencing Batch Reactor Performance For Nitrogen Wastewater Treatment. J Microb Biochem Technol 7: 363-366. doi:10.4172/19485948.1000239

Copyright: () 2015 Le HT, et al. This is an open-access article distributed under the terms of the Creative Commons Attribution License, which permits unrestricted use, distribution, and reproduction in any medium, provided the original author and source are credited. 
to $40 \mathrm{mg} / \mathrm{L}$, while the low $\mathrm{NO}_{2}-\mathrm{N}$ and $\mathrm{NO}_{3}-\mathrm{N}$ of less than $1 \mathrm{mg} / \mathrm{L}$ was found in the influent. The fresh influent was prepared and immediately replaced with the $80 \%$ of water level in the reactor.

\section{Reactor set-up and operation}

The lab-scale 15-L SBR was set-up by adding $2 \mathrm{~L}$ of dense sludge taking from an aerobic wastewater treatment plant of Wangthong Hospital (Phitsanulok, Thailand) and $10 \mathrm{~L}$ of synthetic wastewater. Two spargers for air supply were set-up at the base of the reactor, and a stirrer was controlled at $200 \mathrm{rpm}$ for circulating the water and sludge.

The typical operation was modified from the previous results by the authors [21]. The reactor was operated under 3 cycles of aerating of $3 \mathrm{~h}$, non-aerating of $4 \mathrm{~h}$ and settling of $1 \mathrm{~h}$. Filling and decanting were approximately $5 \mathrm{~min}$ at the first and last cycles (Figure 1 ). In the aeration, air was supplied at the flow rate of $0.5 \mathrm{~L} / \mathrm{min}$ and the DO was around 5-6 mg/L. The DO was immediately dropped to $0.5 \mathrm{mg} / \mathrm{L}$ in the non-aeration, then approximately $50 \mathrm{~mL}$ of acetate solution was added in the first non-aeration to maintain the $\mathrm{C} / \mathrm{N}$ ratio of $2[21]$.

\section{Analytical methods}

The synthetic wastewater (influent) and treated water (effluent) were sampled for $\mathrm{NH}_{4}-\mathrm{N}, \mathrm{NO}_{2}-\mathrm{N}$ and $\mathrm{NO}_{3}-\mathrm{N}$ analysis in accordance with the standard method [22]. The nitrogen removal efficiency was calculated, as present in Equation 1. The chemical oxygen demand (COD) in the effluent was determined using COD analyzer (AL200 COD Vario, Aqualytic). The mixed liquor suspended solids (MLSS) and mixed liquor volatile suspended solids (MLVSS) were measured after filtration and drying at $105^{\circ} \mathrm{C}$ [22]. Moreover, the $\mathrm{pH}$ and $\mathrm{DO}$ were frequently measured using $\mathrm{pH}$ meter (Eutech Instruments) and DO meter (CyberScan DO 110 Model).

To measure the $\mathrm{NH}_{4}-\mathrm{N}$ removal rates, the water samples were taken every $0.5 \mathrm{~h}$ from the reactor operating under continuously air supply, and the reduction of $\mathrm{NH}_{4}-\mathrm{N}$ referred to the $\mathrm{NH}_{4}-\mathrm{N}$ removal rate. Similarly, the reduction of total nitrogen including $\mathrm{NH}_{4}-\mathrm{N}, \mathrm{NO}_{2}-\mathrm{N}$ and $\mathrm{NO}_{3}-\mathrm{N}$ in the reactor operating under no air supply and excess acetate was used to refer to the nitrogen removal rate.

$$
\text { Efficiency }=\left(1-\frac{\left[\mathrm{NH}_{4}-\mathrm{N}\right]_{\text {effluent }}+\left[\mathrm{NO}_{3}-\mathrm{N}\right]_{\text {effluent }}+\left[\mathrm{NO}_{2}-\mathrm{N}\right]_{\text {effluent }}}{\left[\mathrm{NH}_{4}-\mathrm{N}\right]_{\text {influent }}}\right) \times 100(1)
$$

\section{Results and Discussion}

The influent $\mathrm{NH}_{4}-\mathrm{N}$ fed to the reactor was started at $10 \mathrm{mg} / \mathrm{L}$ for being acclimatization. As shown in Figure 2, the nitrogen removal efficiency was relatively low of $<10 \%$ in the beginning, and the efficiency was continuously increasing up to $\sim 36 \%$ in a week. The $\mathrm{NH}_{4}-\mathrm{N}$ was approximately $6.8 \mathrm{mg} / \mathrm{L}$ was found in the effluent, while no $\mathrm{NO}_{2}-\mathrm{N}$ and $\mathrm{NO}_{3}-\mathrm{N}$ was observed (Table 1). This present the low existence of microorganisms responsible for nitrogen removal in the initial sludge. The nitrogen removal efficiency was increasing to $~ 50 \%, \sim 64 \%$ and $~$ $82 \%$, when the influent $\mathrm{NH}_{4}-\mathrm{N}$ was continuously increased to 20,30 and $40 \mathrm{mg} / \mathrm{L}$ respectively. This revealed that the number of responsible microorganisms was increased by influent $\mathrm{NH}_{4}-\mathrm{N}$ concentrations. The significant evidence to confirm the increasing responsible microorganisms in the reactor was that the specific nitrogen removal rate continued to increase during operation, as summarized in Table 1. The value was gradually increased from $4.04 \mathrm{mg} \mathrm{N} / \mathrm{g}$ MLVSS.h at $\mathrm{NH}_{4}-\mathrm{N}$ of $10 \mathrm{mg} / \mathrm{L}$ and reached to $4.2 \mathrm{mg} \mathrm{N} / \mathrm{g}$ MLVSS.h at $\mathrm{NH}_{4}-\mathrm{N}$ of $40 \mathrm{mg} / \mathrm{L}$. The majority of nitrogen in the effluent was $\mathrm{NH}_{4}-\mathrm{N}$ (approximately 6-12 mg/L), while low values of $\mathrm{NO}_{2}-\mathrm{N}$ and $\mathrm{NO}_{3}-\mathrm{N}$ (of $<2 \mathrm{mg} / \mathrm{L}$ ) were remained. It can be note that the process of nitritation was the rate-limiting step in this reactor, although the excess oxygen of 5-6 mg/L was maintained.

Regarding the first cycle operation, the $\mathrm{NH}_{4}-\mathrm{N}$ concentration was dramatically decreased in the aerating period, while high $\mathrm{NO}_{2}-\mathrm{N}$ was generated (data not shown). The generated $\mathrm{NO}_{2}-\mathrm{N}$ was decreased immediately in the non-aerating period, and together with the reduction of total nitrogen and carbon concentrations. This phenomenon suggested that the nitrogen contaminant was removed by partial nitrification and denitrification. Due to the high DO of 5-6 mg/L in the aerating period, the lack of nitrite oxidizing microorganisms was the key reason for partial nitrification occurred in this reactor. However, the further study on microbial test is required to clarify the nitrogen removal mechanisms.

Since the acetate addition was controlled at the $\mathrm{C} / \mathrm{N}$ ratio of 2 , which was sufficient for simultaneous nitrification and denitrification $[21,22]$, the ratio of carbon consumed and nitrogen removed (carbon consumption) was used as an indicator to define the reactor

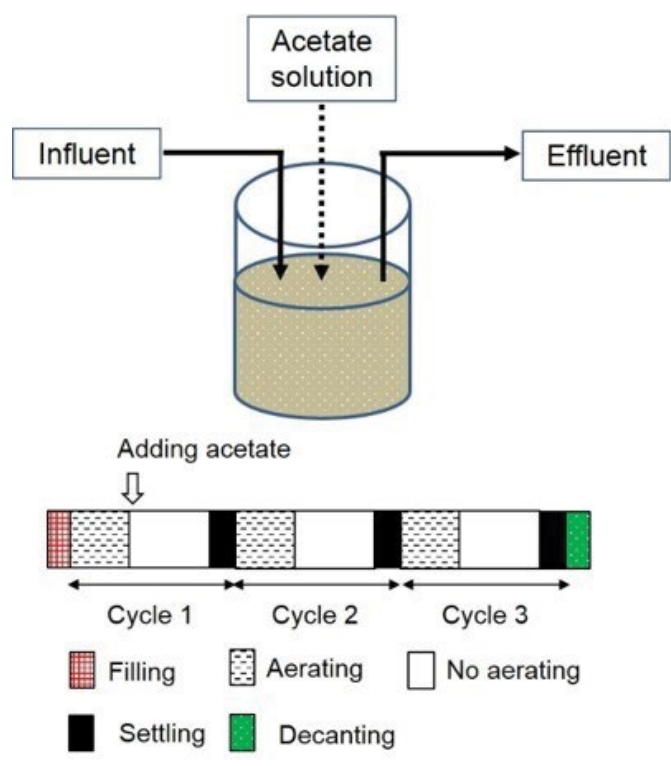

Figure 1: Schematic diagram of SBR operation in this study.

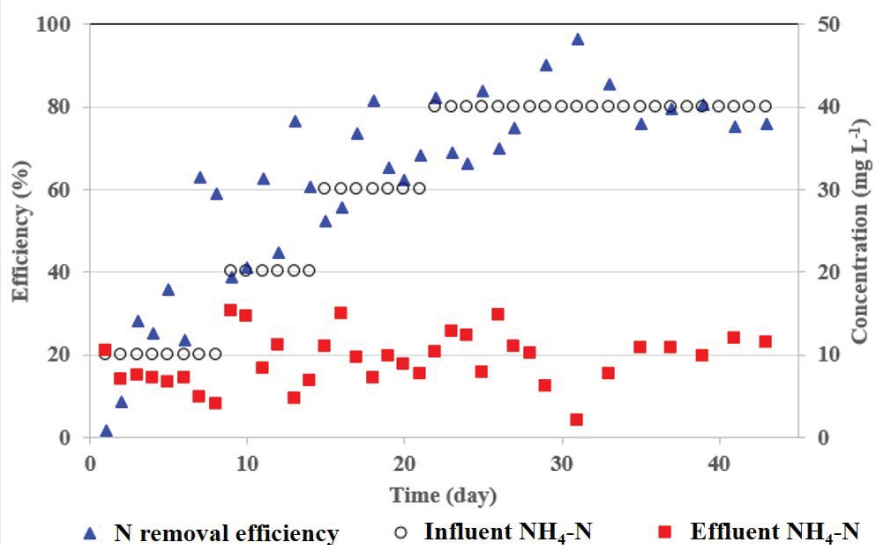

Figure 2: Change of nitrogen removal efficiency and effluent $\mathrm{NH}_{4}-\mathrm{N}$ concentrations during increasing influent $\mathrm{NH}_{4}-\mathrm{N}$ concentrations. 
Citation: Le HT, Jantarat N, Khanitchaidecha W, Ratananikom K, Nakaruk A (2015) Development of Sequencing Batch Reactor Performance For Nitrogen Wastewater Treatment. J Microb Biochem Technol 7: 363-366. doi:10.4172/1948-5948.1000239

\begin{tabular}{|c|c|c|c|c|c|c|c|}
\hline \multirow{2}{*}{$\begin{array}{c}\text { Influent } \mathrm{NH}_{4}-\mathrm{N} \\
\text { concentration }(\mathrm{mg} / \mathrm{l})\end{array}$} & \multirow{2}{*}{$\mathrm{C} / \mathrm{N}$ ratio } & \multicolumn{3}{|c|}{ Average effluent concentration (mg/L) } & \multirow[b]{2}{*}{ Efficiency (\%) } & \multirow{2}{*}{$\begin{array}{l}\text { Specific N removal rate } \\
\text { (mg N/g MLVSSh) }\end{array}$} & \multirow{2}{*}{$\begin{array}{c}\text { C consumption (mg C } \\
\text { consumed/mg N removed) }\end{array}$} \\
\hline & & $\mathrm{NH}_{4}-\mathrm{N}$ & $\mathrm{NO}_{2}-\mathrm{N}$ & $\mathrm{NO}_{3}-\mathrm{N}$ & & & \\
\hline 10 & 2.0 & $6.8 \pm 6$ & $0.0 \pm 0.1$ & $0.0 \pm 0.1$ & $36 \pm 26$ & $4.04 \pm 0.01$ & $5.5 \pm 0.1$ \\
\hline 20 & 2.0 & $11.1 \pm 4$ & $0.3 \pm 0.1$ & $0.2 \pm 0.1$ & $50 \pm 15$ & $4.11 \pm 0.01$ & $4.0 \pm 0.1$ \\
\hline 30 & 2.0 & $9.7 \pm 3$ & $0.4 \pm 0.2$ & $1.4 \pm 0.2$ & $64 \pm 6$ & $4.17 \pm 0.01$ & $3.1 \pm 0.1$ \\
\hline 40 & 2.0 & $8.5 \pm 2$ & $1.8 \pm 0.2$ & $1.7 \pm 0.2$ & $82 \pm 3$ & $4.20 \pm 0.01$ & $2.4 \pm 0.1$ \\
\hline
\end{tabular}

Table 1: Average concentrations of effluent $\mathrm{NH}_{4}-\mathrm{N}, \mathrm{NO}_{2}-\mathrm{N}$ and $\mathrm{NO}_{3}-\mathrm{N}$ at various influent $\mathrm{NH}_{4}-\mathrm{N}$ concentrations.

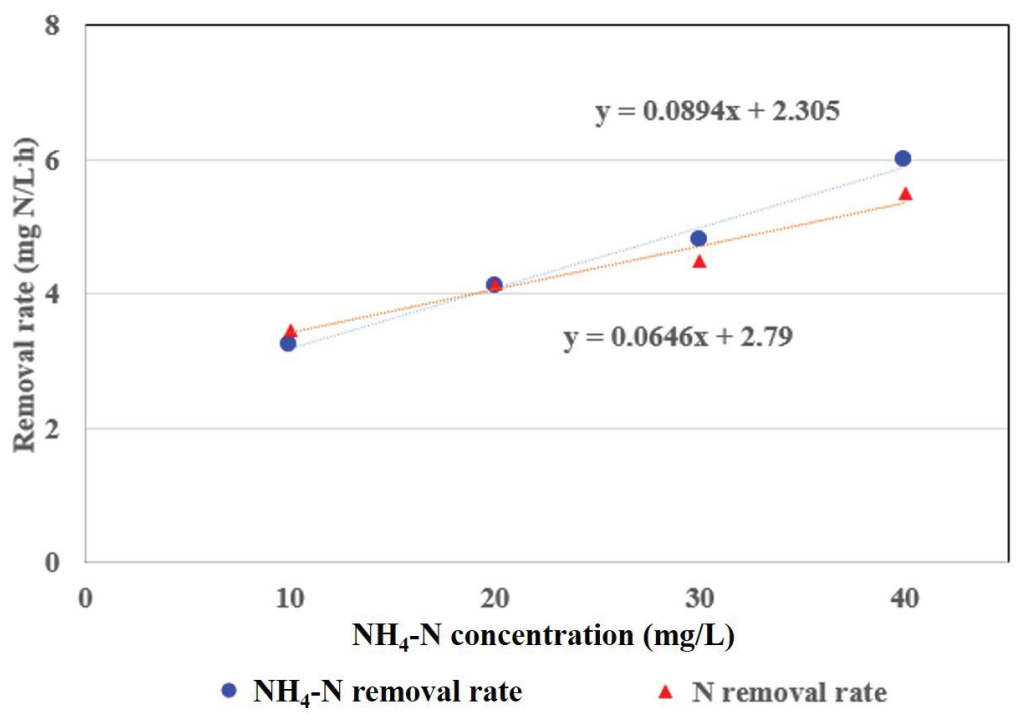

Figure 3: Change of $\mathrm{NH}_{4}-\mathrm{N}$ and nitrogen removal rates during increasing influent $\mathrm{NH}_{4}-\mathrm{N}$ concentrations.

\begin{tabular}{|c|c|c|c|c|c|}
\hline SBR cycle & HRT (d) & Influent $\mathrm{NH}_{4}-\mathrm{N}(\mathrm{mg} / \mathrm{L})$ & Carbon & Efficiency (\%) & Reference \\
\hline $\begin{array}{l}\text { Filling } 5 \mathrm{~min} \text {, Non-aerating } 1.5 \mathrm{~h} \text {, Aerating } 4 \mathrm{~h} \text {, Settling } 5 \mathrm{~min} \text {, } \\
\text { Decanting } 0.2 \mathrm{~h} \text { and Idling } 0.2 \mathrm{~h}\end{array}$ & 0.3 & 35 & $\begin{array}{l}\text { Acetate } \\
(\mathrm{C} / \mathrm{N}=3)\end{array}$ & $61 \%$ & Wang et al. 2009 \\
\hline Aeration 0.5 h, Non-aerating 2.8 h, Settling 1 h, and Idling $0.5 \mathrm{~h}$ & 3.6 & 35 & $\begin{array}{c}\text { Acetate } \\
(\mathrm{COD} / \mathrm{N}=20)\end{array}$ & $>90 \%$ & Li and Irvin 2007 \\
\hline $\begin{array}{l}\text { Fillling } 5 \mathrm{~min} \text {, Aaerating } 3 \mathrm{~h} \text {, Non-aerating } 4 \mathrm{~h} \text {, Settling } 1 \mathrm{~h} \text { and } \\
\text { Decanting } 5 \mathrm{~min}\end{array}$ & 1 & 40 & $\begin{array}{l}\text { Acetate } \\
(\mathrm{C} / \mathrm{N}=2)\end{array}$ & $82 \%$ & This study \\
\hline $\begin{array}{l}\text { Filling (instantaneous), Reacting } 7.5 \mathrm{~h} \text {, Settling } 0.5 \mathrm{~h} \text {, Decanting } \\
\text { (instantaneous) and Idling } 4 \mathrm{~h}\end{array}$ & 0.5 & 40 & $\begin{array}{c}\mathrm{N} / \mathrm{A} \\
(\mathrm{C} / \mathrm{N}=10)\end{array}$ & $85 \%$ & Guo et al. 2013 \\
\hline $\begin{array}{l}\text { Fillling } 1 \mathrm{~h} \text {, Aerating } 3 \mathrm{~h} \text {, Settling } 1 \mathrm{~h} \text {, Decanting } 10 \mathrm{~min} \text { and Idling } 0.8 \\
\mathrm{~h}\end{array}$ & 0.3 & 50 & $\begin{array}{c}\mathrm{N} / \mathrm{A} \\
(\mathrm{COD} / \mathrm{N}=8)\end{array}$ & $98 \%$ & Chen et al. 2015 \\
\hline Filling, Aerating $1 \mathrm{~h}$, Non-aerating $1 \mathrm{~h}$, Settling $0.5 \mathrm{~h}$, Decanting $0.8 \mathrm{~h}$ & 7.5 & 50 & $\begin{array}{l}\text { Ethanol } \\
(\mathrm{C} / \mathrm{N}=3.5)\end{array}$ & $98 \%$ & Guo et al. 2007 \\
\hline $\begin{array}{l}\text { Filling } 2 \mathrm{~min} \text {, Aeration } 4.2 \mathrm{~h} \text {, Non-aerating } 1.5 \mathrm{~h} \text {, Setting } 0.8 \mathrm{~h} \text {, } \\
\text { Decanting } 0.3 \mathrm{~h}\end{array}$ & 0.5 & 80 & $\begin{array}{c}\text { Metanol } \\
(\mathrm{COD} / \mathrm{N}=3)\end{array}$ & $>90 \%$ & Wu et al. 2007 \\
\hline
\end{tabular}

Table 2: Performance of SBR for nitrogen wastewater treatment.

performance and microorganisms' activity. At the low $\mathrm{NH}_{4}-\mathrm{N}$ of 10 $\mathrm{mg} / \mathrm{L}$, around $5.5 \mathrm{mg} \mathrm{C}$ was consumed to remove one gram of nitrogen. The carbon consumption was reduced to 4.0 and $3.1 \mathrm{mg} \mathrm{C} / \mathrm{mg} \mathrm{N}$ at the higher $\mathrm{NH}_{4}-\mathrm{N}$ concentrations. The effective carbon consumption of $2.4 \mathrm{mg} \mathrm{C} / \mathrm{mg} \mathrm{N}$ was found at the highest $\mathrm{NH}_{4}-\mathrm{N}$ of $40 \mathrm{mg} / \mathrm{L}$, referring that the carbon was utilized efficiently for denitrification process and very low carbon was utilized by other competitive heterogeneous microorganisms.

In addition, the $\mathrm{NH}_{4}-\mathrm{N}$ and nitrogen removal rates at various influent $\mathrm{NH}_{4}-\mathrm{N}$ concentrations were present in Figure 3. At the low $\mathrm{NH}_{4}-\mathrm{N}$ of $10 \mathrm{mg} / \mathrm{L}$, the removal rates for $\mathrm{NH}_{4}-\mathrm{N}$ was $3.2 \mathrm{mg} / \mathrm{L} \cdot \mathrm{h}$ and that for nitrogen was $3.5 \mathrm{mg} / \mathrm{L} \cdot \mathrm{h}$. Both removal rates were continuously increasing up to 6.0 and $5.5 \mathrm{mg} / \mathrm{L} \cdot \mathrm{h}$ for $\mathrm{NH}_{4}-\mathrm{N}$ and nitrogen at the highest $\mathrm{NH}_{4}-\mathrm{N}$ of $40 \mathrm{mg} / \mathrm{L}$. These revealed the enhancement of reactor performance by the typical SBR operation. However, the increasing $\mathrm{NH}_{4}-\mathrm{N}$ removal rate was higher than the increasing nitrogen removal rate. This caused the remaining of $\mathrm{NO}_{2}-\mathrm{N}$ and $\mathrm{NO}_{3}-\mathrm{N}$ in the effluent at higher concentrations.

The performance of SBR operating in this study was compared to previous studies which operated under different SBR cycles. From Table 2, it can be seen that the good performance of SBR operating under the typical cycle of aerating of $3 \mathrm{~h}$, non-aerating of $4 \mathrm{~h}$ and settling of $1 \mathrm{~h}$ was obtained at the low carbon addition. Although the long HRT of $24 \mathrm{~h}$ was operated in this study, the HRT can be reduced to approximately $16 \mathrm{~h}$ (two cycles of SBR) with the efficiency of $\sim 80 \%$ (data not shown).

\section{Conclusion}

The SBR operating under three cycles of aerating of $3 \mathrm{~h}$, non- 
Citation: Le HT, Jantarat N, Khanitchaidecha W, Ratananikom K, Nakaruk A (2015) Development of Sequencing Batch Reactor Performance For Nitrogen Wastewater Treatment. J Microb Biochem Technol 7: 363-366. doi:10.4172/1948-5948.1000239

aerating of $4 \mathrm{~h}$ and settling of $1 \mathrm{~h}$ can remove nitrogen from the wastewater effectively. The best performance of $82 \%$ was found at the highest $\mathrm{NH}_{4}-\mathrm{N}$ of $40 \mathrm{mg} / \mathrm{L}$. The average effluent $\mathrm{NH}_{4}-\mathrm{N}, \mathrm{NO}_{2}-\mathrm{N}$ and $\mathrm{NO}_{3}-\mathrm{N}$ were $8.5,1.8$ and $1.7 \mathrm{mg} / \mathrm{L}$ respectively. The increase in active microorganisms for nitrification and denitrification enhanced the removal rates of $\mathrm{NH}_{4}-\mathrm{N}$ and nitrogen at the higher $\mathrm{NH}_{4}-\mathrm{N}$ concentrations. In addition, the carbon consumption and specific nitrogen removal rate were also more effective rather than a low $\mathrm{NH}_{4}-\mathrm{N}$ concentration.

\section{References}

1. Pollution Control Department, Ministry of Natural Resource and Environment Thailand. 2015.

2. Liu X, Dong C (2011) Simultaneous COD and nitrogen removal in a microaerobic sludge reactor for domestic wastewater treatment. Systems Engineering Procedia 1: 99-105.

3. Guadie A, Xia S, Zhang Z, Guo W, Ngo HH, et al. (2013) Simultaneous removal of phosphorus and nitrogen from sewage using a novel combo system of fluidized bed reactor-membrane bioreactor (FBR-MBR). Bioresour Technol 149: 276-285.

4. Orhon D, Genceli EA, Sozen S (2000) Experimental evaluation of the nitrification kinetics for tannery wastewater. Water SA, 26: 43-50.

5. Huo S, Wang Z, Zhu S, Zhou W, Dong R, et al. (2012) Cultivation of Chlorella zofingiensis in bench-scale outdoor ponds by regulation of $\mathrm{pH}$ using dairy wastewater in winter, South China. Bioresour Technol 121: 76-82

6. Gao JL, Oloibiri V, Chys M, Wandel SD, Decostere B, et al. (2015) Integration of autotrophic nitrogen removal, ozonation and activated carbon filtration for treatment of landfill leachate. Chemical Engineering Journal 275: 281-287.

7. Ji F, Zhou Y, Pang A, Ning L, Rodgers K, et al. (2015) Fed-batch cultivation of Desmodesmus sp. in anaerobic digestion wastewater for improved nutrient removal and biodiesel production. Bioresource Technology 184: 116-122.

8. Pommerening-Röser A, Koops HP (2005) Environmental pH as an important factor for the distribution of urease positive ammonia-oxidizing bacteria. Microbiol Res 160: 27-35

9. Ying $M$, Lin W, Lumin Q (2008) Community structure of ß-Proteobacterial ammonia-oxidizing bacteria in prawn farm sediment. Progress in Natural Science 18: 679-684.
10. Deni J, Penninckx MJ (2004) Influence of long-term diesel fuel pollution on nitrite-oxidising activity and population size of Nitrobacter spp in soil. Microbiol Res 159: 323-329.

11. Wei Z, Xinlong B, Limin Z, Anqi W, Yongzhen P (2014) Population dynamics of nitrifying bacteria for nitrification achieved in Johannesburg (JHB) process treating municipal wastewater. Bioresource Technology 162: 30-37.

12. Seung $H$, Suk S, Kyungmoon $P$, Young Je (2005) Novel hybrid immobilization of microorganisms and its applications to biological denitrification. Enzyme and Microbial Technology 37: 567-573.

13. Enrico T, Claudia G, Martin C, Sophie W, Bernie J, et al. (2014) Influences of over winter conditions on denitrification and nitrous oxide-producing microorganism abundance and structure in an agriculture soil amended with different nitrogen sources. Agriculture, Ecosystems and Environment 183: 4759.

14. Liu D, Zhang S, Zheng Y, Shoun $H$ (2006) Denitrification by the mix-culturing of fungi and bacteria with shell. Microbiol Res 161: 132-137.

15. Li B, Irvin S (2007) The comparison of alkalinity and ORP as indicators for nitrogen and denitrification in a sequencing batch reactor (SBR). Biochemical Engineering Journal 24: 248-255.

16. Chu L, Wang J (2011) Nitrogen removal using biodegradable polymers as carbon source and biofilm carriers in a moving bed biofilm reactor. Chemical Engineering Journal 170: 220-225.

17. Yang S, Yang F (2011) Nitrogen removal via short-cut simultaneous nitrification and denitrification in an intermittently aerated moving bed membrane bioreactor. J Hazard Mater 195: 318-323.

18. Guo J, Zhang L, Chen W, Ma F, Liu H, et al. (2013) The regulation and control strategies of a sequencing batch reactor for simultaneous nitrification and denitrification at different temperatures. Bioresource Technology 133: 59-67.

19. Rodríguez DC, Pino N, Peñuela G (2011) Monitoring the removal of nitrogen by applying a nitrification-denitrification process in a Sequencing Batch Reactor (SBR). Bioresour Technol 102: 2316-2321.

20. Guo J, Yang Q, Peng Y, Yang A, Wang S (2007) Biological nitrogen removal with real-time control using step-wise SBR technology. Enzyme and Microbial Technology 40: 1564-1569.

21. Le STT, Khanitchaidecha W, Nakaruk A (2015) Effect of aeration rates on simultaneous nitrification and denitrification in intermittent aerated bioreactor. Asian Journal of Microbiology, Biotechnology \& Environmental Sciences.

22. APHA (1998) Standard method for the Examination of water and waste water (20thedn), American Public Health Association, Washington. 